\title{
Analysis of International Terrorism Criminography in the Event of September 11th, 2011
}

\author{
Mohamad Esmael Zadeh ${ }^{1}$, Mahdi Najjar Sadeghi ${ }^{2} \&$ Amir Mohammad Babaee ${ }^{2}$ \\ ${ }^{1}$ Islamic Azad University, Sari Branch, Iran \\ ${ }^{2}$ Islamic Azad University, Qeshm International Branch, Iran \\ Correspondence: Mohamad Esmael Zadeh, Islamic Azad University, Sari Branch, Iran. E-mail: \\ mohamadesmaelzadeh@yahoo.com
}

Received: January 21, 2016 Accepted: February 16, 2016 Online Published: March 31, 2016

doi:10.5539/jpl.v9n2p138 URL: http://dx.doi.org/10.5539/jpl.v9n2p138

\begin{abstract}
Terrorism and terroristic system are among domestic, regional and international challenging problem in the first decade of the 21 st century in the era when terrorism has turned from an individual threat to a global problem as a weapon to achieve national goals, specific groups have become no longer limited to national and regional borders and are gaining new concept and application (or they are trying to develop a new international purpose). It is feared that the spread of international peace and security in its all areas exposed to risk. In fact, the international communities felt the crisis and the danger and criminalizing this phenomenon after the attack on the twin towers of the world trade center on September 11, 2001 with unknown purposes in New York City [29] determining the failure of the international anti-terrorism strategies of these events, showed that anti-terrorism system is unsuccessful. So shortly after the attacks, the UN Security Council ${ }^{1}$, recognizing the possibility of resorting to self-defense against international terrorism, subjects of international law again to pass the international anti-terrorism calls for conventions domestic laws to crack down terrorists.
\end{abstract}

Keywords: terrorism, the security council, public order, universal jurisdiction

\section{Terrorism Structuralism}

errorism is derived from "terror" ${ }^{2}$, meaning "causing fear and panic among people" or others. Oxford Dictionary defines the term stated "The Growing Fear: a person or thing that will generate a growing panic"[20:1233]. It goes on to define terrorism as violating for political purposes or for an act or omission by creating panic among people[20]. Dehkhoda's Dictionary defines it as follows: "Derived from the French word meaning political murder using weapon, until it was used as Arabic word "ARHAB" instead of Terror which means Fear or Panic in French language...". Moreover, terrorism implies authorities of pressure and panic.in Persian, it refers to a fact which defend political murders and assassination"[5]. In other words, terrorism is a kind of authority which terrifies and cracks down people by confining, executing and other illegal pressures, it includes a leftist or rightist method which commits murder, kidnapping and sabotage to overthrow or threaten Government. Terror is meant to be used for political killings and those who carry out political killings are called " terrorists "[5]. From of terror mentioned above are derived from political situation going on in the late 19th Century in France.[1:195]

\subsection{History of Terrorists}

The use of the word with its positive and reformist concept popularized during French Revolution. During years of 1793 and 1794, Terror system ${ }^{3}$ was considered as a useful tool for setting discipline in transition period after revolution. Put better, in this period revolutionary state used terrorism as a means of terrifying and Cracking down anti-Revolutionist and rivals, i.e people consider it enemies of the nation at the time. However, terrorist conducts at the time at the time had two major traits:

First, contrary to today's terrorist conducts at the time were neither collective, nor discriminatory. In other words, the terrorist conducts were organized deliberate and systematic with the purpose of omitting specific people

\footnotetext{
${ }^{1}$ United Nations security council

2 Terror

${ }^{3}$ Regime dela Terreur
} 
known as betrayers to revolutionist nation.

Secondly, like today's terrorist conducts, the conduct in the French also had the objective of a creating a better Modern Society rather than corrupt and non-domestic political system[4:9].The conducts and abuse of revolution leaders, gradually uncover the anti-humanistic and harsh figure of the phenomenon. Executing more than 40 thousands, under the protection of recording the revolution in and out of France. Especially England which introduced revolutionist terrorist, where blameworthy because that was not meant first. After the French revolution the International ideological development such as communism which were in turn a reaction to capitalism growing from industrial revolution approached terrorism with its modern meaning,at the time the development the revolution anarchy groups led to many terrorist conducts mostly with purposes. The assassination of Russian (Tazar) 1881 and William Mckinly ${ }^{4}$ murder-the American president in 1905 by an Austrian refugee is among terrorist attack with the ideological background and far from its original purposes. Although Mckinley's murder was not a murder of any anarchy groups but a philosophical idea was considered the main actor besides revolutionary terrorism growth, the appearance of the nation's Seniority was an introduction to supprissionist and independent terrorism. Along with the Growth of revolutionary Terrorism the emergence of emergence of the right of nations to Self-Determination then,in order to partion the Ottoman Empire and the Hasburg promoted in Europen Governments and America, it built up the growth of revolutionary terrorism. in this context, two revolutionary organizations Macedonia and young Bosnia were parts of independent Movements that resorted terrorist methods to achieve their goals[19:43]. The most important assassination that took place in that period,was the assassination of the Austrian Crown Prince Franz Ferdynand $^{5}$ - in Sarajevo by a member of the Bosnian Youth Organization Called Gavrylv Principe ${ }^{6}$ on 28th June 1914 that provided the premises to the First World War. The profile of Terrorism in this period,in addition to its individual, is its anarchy or Anti-Government. In a way which is contrary to the reign of terror in the french revolution. In this period of terror not for stabilization, but in order to create Government by weakening the other established Governments (Negative concept and Deconstruction) these terrorist activities were committed by individuals,non-governmental groups, and institution that is more coincident to the concept of Modern terrorism[18]. After this period, the real meaning of terror's policy which is terrifying and intimidating totalitarian authoritarian regimes;such as Nazi, Italian Fascist, Stalinist Soviet Union, Chile and Argentina made again the word terror in favor of a situation where we were not because these Governments benefited the brutal elimination of the protesters, and established its own regime like the reign of terror in the french revolution. While true source of terrorism is the violence perpetrated and committed by non-governmental entities[22:10]. Despite the 18th century as the century in which the word terrorism was officially dynamic Identity, human history and the history of terrorism must be ingrained because it is impossible to separate terrorism from human history. Since man found that he could achieve his political and social aims by creating climate of fear and panic among people,terrorism has become a tool in the hands of political, ethnic, religious and minorities [6:50]. All around the history of Ancient Greece, the roman empire, the Islamic caliphate, America's Civil War and afterwords human still saw the continuation of committing terrorism [6:52], so it should be Highlighted that before the era of Modernity terrorism has been used by religious groups that were under the oppression of the rules. For Example, in the first Century AD, the Jews belonging to Sicari ${ }^{7}$ groups tended to terrorist activities by killing and burning food stocks[19:44] in the 19th century after the U.S Civil War(1861-1865) the south defeated groups had tried to rebuild its lost political power by creating terrorist Organization called Ku Klux Klan ${ }^{8}$. Since then, the international community has witnessed numerous acts of terrorism in which the kings, presidents, ministers, public officials and public places have been targeted and among them the murder of the king Alexander, king of Yugoslavia and Louis Barter, the foreign minister of France. Third decade should be a turning point in the international community in dealing with phenomenon as well.[23:2]

\subsection{Origin of Terrorism}

By recognizing the ultimate purpose of terrorism and mixing the element of its purpose and ultimate result, recognizing the main core of terrorism construction seems difficult; it is clear that the main purpose of any terrorist conducts, regional or international is to create this order and replace it by that of the terrorist. Documents relating to the protection of aviation safety and aviation and anti-terrorism rules by Governments of

\footnotetext{
${ }^{4}$ William Mckinley

${ }^{5}$ Habsburg Archduke Eranz Ferdinand

${ }^{6}$ Gavrylv Principe

${ }^{7}$ Sicari

8
} 
france, China and Canada with the regard to the definition of terrorism by the construction of terrorism, the French penal code pointed to the element "disturbing public order". According to Article 1-421 the serious of terrorist conducts: "in any of the following crime when a person or a group violate the law with the purpose of this orderly conducts will be subject to a terrorist operation[15]. A glance at the concept "public order" simply shows that any legal system tries to preserve public order as the way to keep regime going. The reactions are shown in legal system through criminal punishment; the international legal systems through exceptions either. Although this system is a new system in the international community there are two sets of regulations on peace and human right including the rules meant to preserve public order. International terrorism in fact threatens essential and international order as a means of this orderly conduct. From the view point of the rule of terrorism in weakening peace and international friendly relation, we have to emphasize that preserving peace at the responsibilities of any legal and political system needs preparing regulation to preserve peace, that's why international law has tried to set force rule act, so that despite controversy on the violation considered an international crime violating international public order because peace and recruitment are the main pillar of national consequently international common law in which state should dominate it while there is state power contrary to national law. Tourism like aggression,in other ways threatens public order by targeting the international community. A reference to the first world war under the pretext of the assassination of the crown prince of Austria, the missile strike to Afghanistan by the U.S in 1998 after bombing American Embassies in Tanzania and Kenya by Al-Qaeda proved a crisis between Iran's and American's relations as a result of alleged Iranian support for terrorist groups in Palestine, Lebanon, and most importantly the attack of America and England to Afghanistan in order to wipe Al-Qaeda, the terrorism's rule in cluttering up peace peace and public order and international community and general public. The question here is whether terrorism violates human rights or not? The answer is YES, terrorism threatens law and fundamental freedom in both from committing crime and fighting. So we have to agree that terrorism actually demolates fundamental regulations and rules in the international community i.e regulations and rules which are necessary to observe to protect international public order. Clearly in such circumstances terrorism, regardless of its status in international law, is entitled to all the circumstances of a crime.[3:9]

\section{Types of Terrorism}

As we saw above, terrorism is a violent means used to gain political objective by terrorists. Hence, although the nature of the acts committed is not different from general crime but despite the professional criminals who the objectives are primarily ecenomic, terrorism has been a focus on political objective and to achieve it the most violent crimes are committed so the political domain of terrorist objective is how it is different from professional crimes[18:947]. To clarify this difference, we have to ask this question: although the distinction of terrorism from the other general crimes is the perpetrators' political objective, how is the difference from other political crimes whose perpetrators are given more attentions by lawmakers? The answer lies in the violence that does not exist in political crime, in other words, law makers only consider those acts as political crimes which are not specified by abnormal violence by terrorist conducts. Otherwise this aspect of political perpetrators is exactly one of aspects of terrorism.

\subsection{Domestic Terrorism and International Terrorism}

Depending on the terrorist act in relation to a country and its domestic opposition by going to happen or not domestic terrorism is the terrorism occuring without the involvement of any foreign elements and in connection with a country. Article 3 of the convention on the suppression of 1997[14] terrorist bombings. ${ }^{9}$ considers the issue. on the contrary, international terrorism appears when foreign elements are present. Professor Alikhan ${ }^{10}$ suggests to identify domestic unrest from international political ones which helps us to identify domestic terrorism from the international ones according to him some conditions are necessary to lead to a domestic unrest: "First: the source of unrest is the anti-government group; second: the majority of the groups are in the Government. Third: direct violence group has local objective. Forth: the group does not directly or indirectly receive any financial or military assistance from the foreign Government and on the contrary ${ }^{11}$, political chaos will have international aspects.[18]

\footnotetext{
${ }^{9}$ The convention

${ }^{10}$ Ali Khan is a citizen of Pakistan and a permanent resident of the united states. One of his sons, Majid Khan, was held in extrajudicial detention, in secret interrogation centers, run by the CIA, for four years. On september6,2006 his son majid was transferred to military custody in Guantanamo Bay detention camps in Cuba.

${ }^{11}$ First: the source of unrest is the anti-government group; second: the majority of the groups are in the Government. Third: direct violence group has local objective. Forth: the group does not directly or indirectly receive any financial or military assistance from the foreign Government and on the contrary
} 


\subsection{Individual Terrorism and State Terrorism}

As mentioned above, terrorism was used to refer to state suppressing behavior including antiterrorism groups in the past while in this century, it is used to describe violent behaviour of anti-state groups imposed on civilians and public places as what has been going on in Syria, Irak, and ... in recent years. However, the expression "state terrorism" has been used in the political jargon and in journalistic writing. To show the exact position of the so called separation of "individual terrorism" committed violence recognition among people and governments together with governments is necessary. [4:13]

\section{The Legal Nature of the September $11^{\text {th }}$ Attack}

Introduction, the premise of the reaction of the international rights followers the reactions of different governments regarding September 2001 attack, the question that comes to mind is what the nature of the attack was? Was it a terrorist attack or a military attack?

The importance of the attention of the nature of the attack relies on the fact that on the basis of international law, the victim state "military attack" has a right to legitimate military difference, therefore recognizing the concept of the military attack is really important. Regarding this the international tribune ${ }^{12}$ on Nicaragua in explaining the concept of "armed attack" considered the events between the two countries as military attack if: the attacks included an armed attack, secondly, even if there were casualties on the border line, it can't be military attack. [23:159]

According to article 51 of the United Nations Constitution such an attack gives the right of "legitimate defense". The international law prevents any use of power but for "legitimate defense". September 11, 2001, terrorist attack cannot be considered legitimate but the security councils quick reaction created change in international law. Only one day after the attack the security council set the resolution 1368 "2001" which is worth to note: testifying the principle and objectives of the United Nation Constitution

considering that we have to fight any threats of international peace and security by terrorist activitiesand by identifying the inherent right of individual and collective self-defense forecast in the charter of the United Nations: (1) As clearly as possible, the terrorist attacks of $11^{\text {th }}$ September in New York city condemned Washington DC and Pennsylvania and considered such acts as a threat to international peace and security like any act of international security. (2)It sympathizes with the survivors, families of the victims of the terrorist attacks, the people and the US government. (3) It calls all states urgently to work together to bring the perpetrators and the supporters of the terrorist attacks to justice and says that those who help or support or hide perpetrators, planners and sponsors of these attacks have been responsible and should give explanations for that; (4). And it also calls the international community to double its efforts to prevent and crack down terrorist attacks that include increased cooperation, full implementation of anti-terrorism conventions and the relevant resolutions of the security council, particularly the resolution 1269 (19 October 1999). (5) It expresses the preparation and willingness to take all necessary measures to fight back the terrorist attacks of September 11, 2001, and the fight against all forms of terrorism in accordance with its responsibilities of the United Nations Charter. 6. It also retains the agenda [12]

\subsection{The Reaction of International Law Followers towards Criminalizing Terrorism}

It should be noted that in addition to the achievements of terrorist attacks on September 11, 2001, created in response of the international community to international terrorism, in the light of General Assembly resolutions and Security Council it obtained two important achievements, it's clear that terrorism is capable of threatening and violating international peace and security and humanity and its identity. Therefore, rules for keeping international peace and mankind are empirical, terrorism is in fact an international crime which makes the world's jurisdiction for pursuing those who are accused of perpetrating terrorist activities, however there is no clear global definition of terrorism and prosecution of terrorists [6:70]. This situation has been intensified on basis of agreements in the $12^{\text {th }}$ Anti-terrorism Convention including commitment and duty about criminalizing terrorism in domestic law because this can be referred against the membering countries. September 11, 2001, attack had a strong effect on the above mentioned situation so that it could be said that after the attack an international commitment developed for criminalizing ${ }^{13}$ terrorism in the international community. It is good to note that after their attack, the United Nations secretary general of the time clearly announced the terrorist attack

\footnotetext{
${ }^{12}$ International court of justice(ICJ)

${ }^{13}$ Ordering criminalization crystalized in practice verdicting resolution 1373 in September 28, 2001, apart from its' long background, has its' root in a process of global reaction and the general assembly's resolution.
} 
at a crime against humanity ${ }^{14}$ at September 13.

The Supreme Commisioner for human rights ${ }^{15}$ called terrorism as "a crime against the humanity" in addition to this comment, the UN emphasised that the stated should have international cooperation to prosecute and punish the perpetrators of the terrorist attacks. [8:32] As a result of these comments and the vacuum in the customary rules, in resolution 2001 under chapter VII of the UN charter, the security council requires states to criminalize terrorism in its domestic laws and regulations as it can be inferred by this resolution on the basis of article 25 of the UN Charter, respect for all member states is inevitable. ${ }^{16}$ In addition to the resolution, almost all states emphasize the necessity of defining and criminalizing terrorism to the security council anti-terrorism committee in its report in which this matter proves that its a must for the states to be gathered to criminalize terrorism [8:36].

\subsection{Security Council and Criminalising Terrorism}

Ratifying resolution 2001 the security council set a responsibility for states according to the $7^{\text {th }}$ chapter of the Constitution. According to paragraphs 1-5 of the Constitution, on the basis of the $7^{\text {th }}$ chapter, security council:

1) Decides that every state has to: (a) prevents social resources for terrorism and suppress it. (b) Announce opening toward supporting any direct or indirect account by their own citizens to sponsor terrorism. (c) boycott confiscate any accounts for other financial resources of terrorism perpetrators. This also includes people facilitating any terrorist operation; states that are directly or indirectly owned by these people are also included. (d) It prevents any states citizens or institution present in its territories from any direct or indirect account or financial support for any other services or the following persons: persons who conducted terrorist act or trying to, persons who participated in or facilitated the commition of terrorist acts.Institutions directly or indirectly owned by such people or institutions or people directed by them.

2) Also decides that all states: (a) should avoid any negative or positive support (active or passive) of units or persons related and associated with terrorist acts, for example by suppressing recruitment of terrorist groups and eliminating the supply of weapons to terrorists; (b) should take the necessary steps to prevent terrorist acts by exchanging information with other governments as soon as possible; (c) should prevent appearing as a safe place to those ones who perpetrated or organized or facilitated terrorist acts. (d) shouldn't allow their countries to be used by those ones who perpetrated or organised or facilitated terrorist acts against their citizens; (e) should guarantee that all persons charged with commiting, planning, financing, supporting and facilitating terrorist acts will be brought and presented to justice and also to insure that despite the other steps and measures against them such terrorist acts should be anticipated as serious offenses in domestic laws that much that the legal penalties reflect the importance of crime terrorists for these actions. (f) should get the maximum possible assistance to each other about criminal investigations or prosecutions related to financing or supporting terrorist acts. The assistance can include help to study the necessary documents to prosecute terrorists; (g) the mobilization of the terrorists or terrorist groups in the control borders should be prevented and they should exercise control in the issuance of identity and trip documents.

3) Calls all states to: (a) finding ways to increase and accelerate practical information , especially information related to the actions or terrorist networks; forget travel documents, smuggling weapons, explosives, the use of communication technologies by terrorist groups and the threat organised by the position of mass destruction weapons by terrorist groups; (b) exchanging information in accordance with international and domestic law and cooperate on administrative and judicial matters in order to prevent the commition of terrorist acts; (c) cooperating particularly with through bilateral amd multilateral arrangements and agreements in order to prevent terrorist attacks and take measures against the provision of such actions; (d) being a member of the relevant international conventions related to terrorism and security council resolutions such as resolution 1269 (1999) and 1368 (2001); (e) taking appropriate measures in accordance with relevance provisions of national and international law, including taking international standards of human rights before granting refugee status in order to insure that the asylum keepers are not accused of commiting, planning, participating and facilitating terrorist acts; (f) insuring that the facilitators of terrorist acts do not abuse the refugee status under international law and their political incentive claims to commit terrorist acts does not prevent the defenses from commiting terrorist acts.

\footnotetext{
14 The UN's secretary general: 'a tourist attack in any country implies an attack to humanity in general.

15 www.un.org/news/ossg/sg/index.htm

${ }_{16}$ Moreover, it decides that governments should guarantee that preetraers will attend the court, they have also to guarantee that besides other actions against them, the tourist acts have been or will be considered violent offences so this shows the significance of terrorist offences.
} 
4) It is important to note the close connection betweent international terrorism and transnational organised crime, drugs and currency. In this regard, the security council stressed and emphasized the cooperation at the national, sub-regional and international levels in order for a global response to these serious challenge and threat to international security ... [13]. According to the provisions in paragraphs of the resolutions especially the paragraphs 1 and 2 related to it, it is clear that the council has forecast five main obligations for the governments in fighting terrorism such as: 1. not financing terrorism (paragraph 1a). 2. the security and intelligence cooperation to stop terrorist acts (paragraph 2b). 3. the criminalization of terrorism (article 2E). 4. punishing those ones accused of terrorist crimes (paragraph 2e). 5. international legal aid (paragraph 2), the duties created the obligations that were not customary for the UN member states before the resolution. However, the 12 Anti-terrorism conventions described these tasks to its member states in more details [4:26]. These assignments that were derived and taken by the reviews of all conventions are: 1 . to prevent, prohibit and criminalise terrorist activities. 2. intelligence cooperation. 3. make jurisdiction in order to prosecute those ones accused of terrorist offenses. 4. to punish or extradie those ones who are accused of perpetrating terrorist offenses. 5. to the international legal aid in order to fight terrorists. The result of such analysis is that the security council turned the obligations arising from the UN conventions to organizational obligations throughout its extraordinary courage in fighting terrorism imposed on all member states without a doubt. Although such process is in the international level of "international legislation" which is unique and it considers a reasonable and a great breakthrough to suppress terrorism in international community mobilization.

\subsection{Security Council and the Jurisdiction to legislate in Transnational field}

Law, wether in domestic and international law includes a general judgement the way that the judges measurements are based on law. In international community there is no legislation that means like mentioned above; because basically the states are able to create rules despite the progress and breakthrough achieved in organizing in international community, in such general and universal jurisdiction was exclusively not given to any institution and organ. However, such authority is to determine the legal status of specific issues ${ }^{17}$, solving the international crisis

in particular subject ${ }^{18}$ given to the conventions or international organizations. In other words, in order to not wanting to specify the governorship and power, if the government prevented granting legal legislated jurisdiction to accept the jurisdictions of international organizations because of being a member of the UN; although that acceptance in any case is limited to the case and applicable case unless because of the reported decisions of the organisation and the lock of the member state, such decisions turn to the rule of corporate law which it will be in all cases used. An obvious example for such situation as seen in the advisory opinion of the international court of justice in legal affects of the government regarding the presence of South Africa in Namibia ${ }^{19}$ despite of the resolution 276 (1970) and the security council in which in that court in the position of dealing with legal effects of the resolutions with the abstentions that have been issued in the security council, despite of the fact that the UN charter emphasized the positive votes of all members, it decreed that: "the procedures following the security council did not continually change after amending article 27 of the UN charter in 1965 and have been generally accepted by the members of the UN, hence it can be considered as a general document of the organization" 20 . The resolutions of the security council about Afghanistan can be checked under the legal law and basis. These resolutions imposed non-violated and astonishing assignments on the member states and on the other hand were issued, regardless the situation in Afghanistan; because by referring to the resolutions a point that specifies fighting terrorism in Afghanistan can not be found. Hence, regardless of Afghanistan's situation it can be concluded that the security council made an international legislation to fight terrorism, i.e. it put a (general legislation) to fight terrorism in the international community that despite its benefits in terms of legal issues it put it out of jurisdiction. In this regard, according to article 24 of the UN charter ${ }^{21}$ as "duties and powers", the security council;s main duty is to maintain international peace and security. Despite of the fact of no rights of legislating provisions were given to the security council, it is clear that the UN charter made the security council responsible for maintaining international peace and security, and respecting the principles of the provisions related to chapter 6 and 7, 8 and 12. In this context the right to investigate about the international dispute and

\footnotetext{
17 Marine laws

18 The crisis in Iraq

19 South west Africa

20 According to Paragraph 3 of chapter 37 of the UN, " the UN's decisions on other issues will be taken via the permanent member's positive votes..." while according to the above a neutral vote of any permanent member will be considered a vote.

${ }^{21}$ To gurantee the UN's function quickly and efficienty, the member countries gave the security council the responsibility for global peace and security and they agreed to take actions to help it forward.
} 
whether the dispute can threaten international peace and security was given to the security council in chapter $6 .{ }^{22}$ The authorities for giving advice and making decisions in order to prevent threat and violation of peace were given to the security council in chapter $7 ;^{23}$ as in this case, the council can maintain international peace and security by imposing obligations on member states but the authority of exploitation of regional arrangements has been given to the security council in chapter $8 .{ }^{24}$ So it can be concluded that although the security council took an important step to criminalize terrorism and making an international cooperation to fight against terrorism by adopting the resolution 1374 (2001) which is beneficial for the international community but it went beyond and further than its jurisdiction and what it did was objectionable. Under the article 25 of the UN charter as far as the article obligations are related to Afghanistan's case in the resolution 1373 (2001), the obligations are entered into force otherwise it is subject to the future satisfaction of the member states. In this regard, although over 166 states took the resolution 1373 (2001) into consideration by sending a report to anti-terrorism committee in the first, and the security council's action in adopting the resolution was not under attention or protest by politicians but we have to admit that such luck will only be determining it when it is measured out of the fight against terrorism in Afghanistan [8:40].

\section{Conclusions}

Although the history of terrorism goes back to the mid centuries, the fact is that such phenomenon starting from the second half of the $20^{\text {th }}$ century onwards, has been growing and has had a new identity. Actually it can be due to several factors including the development of technology creating dangerous and powerful weapons, developing relations and globalization among these causes Globalization-Globalising that have a driving and double roles. In fact that's why rapid growth of international terrorism is seen in order to disrupt public order and make chaos in the international community, the international terrorism is trying to affect the states or the organization's international policies, on the other hand, mostly by targeting the innocents it's trying to generate a great shock and fear in the community to achieve its goal which is disrupting public order. The terrorist attacks of 11 September 2001 is considered as one of the milestones that has had a significant impact on the international community. According to the point of view of international law, this phenomenon has three major consequences: firstly they left a great influence on the reaction of an international community and international law followers or international terrorism; secondly, in the event of 11 September 2001 if parts of the states from anti-terrorism conventions are obliged to criminalize terrorism in domestic law after these events the formation of a global task can be discussed and in the last step it is obvious that this event requires the security council to impose all common obligations in anti-terrorism conventions under organizational obligations to all the united member states; as if from now on states are obliged to do the obligations.

\section{References}

Abdollahi, M. (2006). concept of international Terrorism and its' definition in international community, idlib.

Ali, A. M. (2009). international riminal law (a selection of articles), Tehran, Mizan publication, fourth edition.

Baqeri, S., \& Javad, M. (2010). international criminal law (8th ed.). Tehran, Jangal publication.

Case concerning Mitirary \& paramilitary, Activities in and Against Nicaragua, (NicaraguaV.U.S.A), I. C. J. Reports, 1986.

Dehkhoda, A. A. (1999). Dehkhodas' dictionary. Tehran university press.

EsmaelZadeh, M. (2011). study of global jurisdiction principle in international System, and the Iranian law. MA thesis, the Islamic Azad university in Arak.

EsmlaelZadeh, P. A., \& Mohammad, A. (2015). a study of international terrorism with the focus on september 11,2001 attack, to be published.

Hoffmon, B. (2002). From Diffining Terrorism, Inside Terrorism. Terrorism and cuonterrrorism, edited by: howard, D. russel and sawyer, L. reid, Dushkin me grow hill.

https://cnn.com

https://en.wikipedia.org

https://fa.wikipedia.org

${ }^{22}$ Article 34 of UN charter

${ }^{23}$ Article 40 of UN charter

${ }^{24}$ Article 41, 42, 43 of UN charter 
https://icj-cij.org

https://un.org

https://un.org/en/sc

International convention for the suppression terrorist bombings (1997).

Khan, A. (1987). A legal theory of international terrorism. Connecticut law review, (19).

Kolba, T. (1997). universal criminal jurisdiction in matters of international terrorism .some reflections on status and trends in contemporary international law. revue hellenigue De Droit international.

Mohsen, A. (2003). the effects of September 11, 2001 attack on the war against Terrorism. legal information magazine, the Iranian presidency legal and Parliament affairs, year 1.No3.

Mohsen, A. (2006). is terroriosm an international crime?" suppression of terrorism in contemporary international law, research center publication, presidency regulations development, first edition.

Oxford Advanced Learners dictionary, Fifth Edition, 1997.

Tabibifard, A. (2006). challenging financial support of terrorism in international documents. law magazine, (34).

the articles of association of international court of Arbitration.

the convention on condemning terrorist bombings (1997).

the French criminal law.

the security council's resolution 1269 (1999).

the security council's resolution 1273 (2001).

the security council's resolution 1368 (2001).

the security council's resolution 276 (1970).

the UN's charter.

\section{Copyrights}

Copyright for this article is retained by the author(s), with first publication rights granted to the journal.

This is an open-access article distributed under the terms and conditions of the Creative Commons Attribution license (http://creativecommons.org/licenses/by/3.0/). 